\title{
ELIMINATION BY SUBSTITUTION: THE TRAVESTY OF CHANGING CULTURAL NAMES TO BIBLICAL NAMES BY PENTECOSTALS IN SOUTHWESTERN NIGERIA
}

\author{
Samson O. OLANISEBE \\ Department of Religious Studies, \\ Obafemi Awolowo University, Ile-Ife, Nigeria. \\ soolanisebe@yahoo.com, slanisebe@oauife.edu.ng \\ $+23408034227580$ \\ URL: http://ijourels.org.ng $\quad$ https://dx.doi.org/10.4314/ijrs.v7i2.3
}

\begin{abstract}
One of the reasons put forward by Yoruba Pentecostals who engage in the phenomenon of changing cultural names to biblical names is the evil connotation which the meanings of such names exude. This might have been informed by the Yoruba belief that a person's name exerts great influence on the attitudinal and behavioural life-pattern of the person, coupled with what the person becomes in life. However, looking at the meanings of some of the biblical names that the protesting Pentecostals eventually take up, one wonders whether there is any need for such action, when the biblical names to which they change also have negative meanings themselves. This paper raises the question whether the attitude of the Yoruba Pentecostals engaged in name-changing is desirable, or can it be described as a travesty? The paper makes use of literature review on names among the Yoruba and the Hebrew, and unstructured interview with some Pentecostals who have changed their Yoruba cultural names to biblical names. The results are subjected to content analysis and critical evaluation. The study found that many of the biblical names adopted in place of the cultural names also have negative connotations, but the Pentecostals prefer the latter, first because they do not even consider their meanings, and secondly because they often focus on the character and the significant roles those biblical personages played in the biblical narratives. The paper concluded that the action of the Pentecostals could best be described as a travesty of name changing which does not worth its sort.
\end{abstract}

Keywords: Cultural Name, Biblical Name, Name Changing, Pentecostals, Southwestern Nigeria.

\section{Introduction}

One of the emerging trends among Pentecostals in southwestern Nigeria has been the phenomenon of change of Yoruba cultural names to biblical ones. It is to be noted that the phenomenon of name-changing is discernible among Christians of all denominations, but it is more rampant among the Pentecostals. ${ }^{1}$ It is not uncommon to see some of the Pentecostals whose surnames or other names are connected with African traditional religious deities or occupations of their families changing their names. This may involve changing the entire name or a-times modifying the cultural names to divest them of whatever evil or cultural connotations that are believed to be inherent in such names. Thus one 
may hear someone bearing Esubiyi changing to Jesubiyi, Sangowale changing to Oluwale, Oroseyi changing to Oluseyi, etc. At another level, many of the Pentecostals that are engaged in change of names no longer give Yoruba names to their children during naming ceremonies, rather they give biblical and English names to them, such as Mary, Jonah, Praise, Testimony, Treasure, Glory, Innocent, to mention just a few.

Many reasons have been adduced for the phenomenon of name-changing among those who engage in it, such as instruction from God, affinity with the Yoruba divinities, ancestral linkage, demand of new religious identity, forfeiture of benefits, and difficulty in name pronunciation. ${ }^{2}$ This phenomenon, however, is seen as an affront to the Yoruba culture, where names are a mark of cultural identity and where names that people bear can speak volumes about the family and social history of the people. This paper examines the importance of name among the Yoruba, analyses some of the Yoruba names the Pentecostals are changing from, coupled with the biblical names they are changing to, with the aim of ascertaining the travesty or otherwise of the action of the Pentecostals. The paper is descriptive, regarding some of the names that the Pentecostals concerned are changing from and the biblical names they are changing to. Data was gathered through literature review on names among the Yoruba and the Hebrew. The results are subjected to critical evaluation.

\section{Examination of Yoruba Names}

It must be admitted right from the outset that Yoruba etiology has come largely from oral traditions, the traditional society being non-literate. The Yoruba constitute one of the major ethnic groups in Nigeria. According to Lucas, they are undoubtedly one of the leading and most progressive peoples in West Africa. This position they have attained in terms of the ease and rapidity with which the Yoruba assimilate Western ideas, the splendid results achieved by them within the short period between the advent of the British and the present time, the number of leaders produced, and the manifest signs of determination to make improvement in every walk of life. ${ }^{3}$ The Yoruba comprise of many clans which are bounded together by language, traditions, religious beliefs and practices. Geographically, the Yoruba could be found in the present states of Oyo, Ogun, Lagos, Ondo, Ekiti, Osun and some parts of Kwara, Kogi, and Edo States. According to Fadipe, the sub-ethnic groups consist of the Ėgbádò and Àwórì of the İlaròo division of Abéòkúta; the various groups of İjèbú, the Òyó and Ìlorin, the Ifè and İjèsà; the Ondo, the Idoko, Ìkálè and Îlàje; the various small groups of related peoples collectively known as the Èkìtì; the Yàgbà and the İgbómìnà and Okun. ${ }^{4}$ A considerable number of Yoruba people also inhabit the southeastern part of the Republic of Benin (former Dahomey). All these areas referred to, formed what was known as the Yoruba country, before the European partition of Africa. $^{5}$

Naturally, Yoruba people are distinguished from other ethnic groups in Nigeria by their culture which includes language (comprising of so many 
dialects), religion, arts, cultural values such as modes of greeting, respect for elders, live-and-let-live philosophy, community fellow feeling, ișàlejò (hospitality), music and artifacts, the meaningfulness and sociological significance of names and naming, ìwà (character, morality), etc. ${ }^{6}$ Among the traditional Yoruba, names are very significant. When a child is born, on the third day of the birth, the father of the child would contact a diviner to make enquiry about what the child would become in this world. This act is called Àkosèjayé or Ėsèntáyé (the first step into the world). If the diviner revealed that the child would have good fortunes in life, the parents would rejoice, but if it would be bad fortunes, sacrifice would be prescribed for the parents to avert the misfortunes. This forms part of the factors that influence the name to be given to the child.

To the Yoruba, name is a mark of identity. A name, according to Oduyoye, is the linguistic symbol by which you remember an individual. ${ }^{7}$ Our names, according to Emens, are among the first words we are taught to say and write. They are words that we learn early to associate with ourselves. ${ }^{8}$ To the Africans in general, and to the Yoruba in particular, nothing is said to exist until that thing is named. Names are not just abstract terms couched in indefiniteness, they are not mere labels, but they are pregnant with meaningful and of symbolic import. ${ }^{9}$ Names, whether personal or place-names, act as sources of information, facilitate communication, help us to know and serve as repositories of values. ${ }^{10}$ While discussing the relevance of culture to the teaching of second language, Akinyemi demonstrates the importance of using Yoruba personal names as an aspect of culture in the teaching of Yoruba language. To him, the task of the teacher should not stop at mere explanation of Yoruba names and their meanings but rather include an exposition of the links between the names and their cultural content. This is because Yoruba personal names carry specific cultural information about the people's societal values, philosophical thoughts, worldviews, religious systems and beliefs. He reiterates how Yoruba people in the Diaspora have preserved their Yoruba personal names with the sole purpose of reconnecting to their roots, preserving the African identity, reinforcing their sense of communal living, and specifying individual person's lineage, history, professional affiliation and spiritual patronage. ${ }^{11}$ Writing about names, Sofola, a Yoruba scholar notes that,

they tell us who we are, what our thoughts and aspirations are. They express our relations with the Maker. Above all, they represent our attempts to understand the universe and ourselves, our place in the universe and our attempt to achieve order in our human midst. And in as much as they serve these purposes they have meaning to us and help to relate ourselves to the order of things. We do not wish to have them changed and exchanged with others that do not have meaning to us. ${ }^{12}$

In the traditional Yoruba society, names were not just chosen for the fun of it. Rather, certain characteristics, features, or circumstances usually informed the 
names to be given to a child. One of these features was the circumstance that surrounded the birth of a child. This could be in terms of the parts of the body through which the child was born. To these circumstances, Yoruba have readymade names. For example, a child who brought the leg first during birth instead of head was named İgè; the one with the birth sack covering all over the body at birth was named Ọkẹ́. In addition to this, the day of the week when a child was born could also dictate the name to be given. A child could be called "Jọoọ̀sệ" or Abíósè if the birth occurred on Sunday. For a couple who had waited for long before they gave birth to a child, names like "Olúwásínà", meaning "God has opened the door" or Ayọ̀mídé (my joy has come). Moreover, the social-cultural events going on in the society as at the time of birth can also determine the name to be given to a child, hence "Abióndún" (born during a festival), "Abéégúndé" (born during masquerade festival), etc. Mbiti states that weather often reflect in people's names, and that some people are named after thunder, rain, drought, famine, harvest, weeding, hunting, and other seasons of the year. ${ }^{13}$ Hence among the Yoruba, there are such names as "Abéjidé"(born with rainfall), "Abọ́yadé" (one born when River Niger overflows its bank, or during River Niger festival), etc.

The social-economic status of the parents as at the time of birth can also dictate the name to be given a child. Hence, the Yoruba proverb "Ilé làa wò ká tó somo lórúko" (the state of the home is usually considered to name a child). For example, if a child was born when the parents had been visited with good fortune, the name will automatically reflect the situation. Such names include "Olásílé" (for a child whose parents had just packed into their own house), "Kóláwolé" (one who brings affluence into the house, for a child whose birth coincided with the parents' fortune). In contemporary times, there is a saying in relation to the name "Kóláwolé". "Ayálégbé tó bímo tó so ó ní Kóláwolé, nígbà tó báyá, yóò kó olá rè síta" (literally meaning a tenant who gives birth to a child and names it Kóláwolé, in due time, the tenant will carry out his affluence). This is to warn the tenant that the name "Kóláwolé" cannot just be given arbitrarily, but by parents who own their own personal house.

There was the phenomenon of children who died shortly after being born, repeatedly, called "born-to-die" children. Such children receive names, such as "Dúrósinmí" (stay to bury me), "Kòsọ́kọ́" (there is no more hoe to dig your grave), "Fìdímáyé" (stay in the world), etc. Sofola identifies the status of parental relationship with other people in the community as an important factor that determined the name to be given to a child. He holds that:

The great premium which the Africans place on a wholesome relationship with others in their community has its correlate in the moralistic activism among the people. The Yoruba would challenge one another in their proverbs and names to live to moral expectation in the group's altruistic interest. A name such as MÁBÌNÚORÍ (from a kìi bínú orí ká fi filà dédî́, i.e. one does not so much begrudge or envy the head so much that the hat meant to adorn it is placed on the buttocks instead) tells the others in the 
community to give the bearer his due share of honour and not begrudge him as to deny him this honour. Another one is ORÍLONÍSE i.e. it is my good fortune or destiny that makes me what, so please do not begrudge me. For your grudge would be useless and disruptive. Other names in this category are Àánjùwón, Oláníyonu. Aríléyan. ${ }^{14}$

The divinity through whom the child was believed to have been given was another possible factor that can dictate child-naming. That is what J.S. Mbiti calls "names that show religious feelings." In the traditional Yoruba society, high premium was placed on the divinities as an intermediary between Olódùmarè and humans. They would name a child after the divinity through whose intervention they believed the child came. Thus, there are names, such as "Ėsúbíìyí" (Èșù has given birth to this), "Ògúnwálé" (Ògún has come home), "Ọș̣unmáyòwá" (Ộṣun has brought joy), "Șàngófúnké, Șàngókúnlé" (Sàngó has given me to nourish, Sàngó fills the house), "Ifábùnmi" (the oracle gave me), "Eégúngbohùn" (Masquerade heard my voice/cry), etc. Quarcoopome puts it succinctly thus:

If the pregnancy was in response to petitions made to a divinity, then the child's name is compounded with that of the divinity to establish that fact e.g. Sàngóbùnmi meaning Sàngó gave me. ${ }^{16}$

Moreover, the belief in reincarnation still persists, even though on a small scale, in the contemporary Yoruba setting. One of the respondents interviewed, disclosed that there are some mysteries behind the issue of re-incarnation which she could not understand in the light of her Christian faith. When her husband died, her firstborn who was a female and had married was already pregnant. So not quite long she delivered a baby boy. When the boy was about age six in 1998, he started behaving to his grandmother in a peculiar way different from that of other children and grandchildren. The respondent said:

This son loved me and would keep his money for food in the school with the aim of assisting me because he knew I was not having proper care. At times, he would look at me and say that he knew that I was suffering but that I should not worry for he would take care of me. One day, he called me and said "what of my cutlass that I put beside the banana tree a day to the day I died?' I was shocked when I heard this because, we were at Omí-Àdió when my husband died and this boy had never been to Ọmí-Àdió all his days. And of a truth my husband went to the farm a day before his death and kept his cutlass beside a banana tree. Since that day I kept on looking at the boy mysteriously. Could it be that he has heard the story from someone? Or could it be just a sheer coincidence? Or could it be that the Yoruba belief in re-incarnation is true? This I could not tell.,"17

One should not gloss over the fact that the baby was conceived even before the grandfather died as related by the interviewee. Her experience is rated as private revelation. What do the people actually believe? Abioje (2014: 18) found that 
such names as Babátúndé (Father returns), İyábò or Yétúndé (Mother returns) given to children born after the death of a grandfather or grandmother, "which several scholars have interpreted as implying Yoruba belief in reincarnation, are only consolatory names", coming as "natural reaction, saying a new baby represents (if not replaces -emphasis his) the lost grandfather or grandmother."18 Abioje thus found from the repositories of Yoruba belief that he interviewed that the names are in tandem with the pattern of naming children in accordance with the mood of the parents as at time of the birth of a baby, rather than belief in reincarnation.

In another vein, family occupation could determine the name to be given to a child. For instance, if hunting was the family occupation, names like 'Odẹ́biìyí' (Hunter gave birth to this one), 'Odẹ́rìndé' (Hunter walks-in), 'Odẹ́bùnmi' (Hunter gave me), etc. were normally given. If the family occupation was art or craft, names like 'Onàyẹmí' (Art suits me), 'Onàlàjà' (Art settles the quarrel), 'Ònàbàjò' (the artist returns from a journey) etc were usually given. If the occupation was drumming, names like "Àyándélé, Àyántọ́lá, and Aláyándé" etc. were usually given, meaning "the drummer reaches home, drumming is sufficient honour, and here comes the master of drums, respectively". ${ }^{19}$

However, in the contemporary Yoruba society, many of these factors influencing names to be given to a child are no longer in operation or have been relegated to the background, all thanks to modernity, western education, and "foreign" adopted religions. For example, in contemporary society, among the Christians, there are no names compounded with divinity, rather majority of the names are compounded with "Olúwa" (Lord), usually shortened to "Olú". Also, children born during festive periods are no longer given names reflective of those festivals. One important major departure from the traditional naming system by the Pentecostals is the fact that names given to children have more English and biblical names than Yoruba. The phenomenon is of course noticeable among all Christians, but it is more pronounced among the Pentecostals. Many of the names are biblical adjectives with positive connotations. These names include Joy, Peace, Grace, Treasure, Testimony, Breakthrough, Mercy, Goodness, to mention a few. Even in a situation where the child is given a Yoruba name people tend to call him or her by the English name. One may then ask, is this a result of the influence of Christianity, civilization, education, personal preference or cultural devaluation?

\section{Biblical Names being changed to by the Pentecostals and their Meanings}

Name is very significant also in the Bible, just like among the Yoruba, the names of people in the Bible are culturally conditioned and reflect different times and seasons in the development of the people of the Bible. Like the Yoruba, there was time when animism, the belief that things in nature, e.g. trees, mountains, sky, etc., have souls, was being practiced among the Hebrews and the names given to people around the time reflected that belief. Among the Hebrews, 
many factors dictated the names to be given to a child at birth. Some of these factors included circumstances surrounding the birth of the child, the traits discernible in a child, the religious and social occasions happening during the birth of the child, and many others. These factors, which influenced the names given to children among the Hebrews, will be explained better in connection with Hebrew proper names that are discussed below.

It must be recalled that the Hebrew proper names could be studied and analysed from the place names and names of persons. This is further confirmed by the fact that personal names and place names are sometimes related. According to Abba, "personal names, in some instances are derived from names of places and place names, on other occasions, from names of persons." 20 In terms of the classification of Hebrew proper names, Abba mooted that Hebrew proper names can be classified into two broad groups - simple and compound names. However, Gray, while not contending Abba's classification, has identified the third classification, which he calls "abbreviations or modifications of what was originally sentence-name in which one element is simply not omitted but is replaced by an ending.

Simple names among the Hebrews consist of names with only one element, which is essentially an epithet. Examples include Jacob which means 'Supplanter'; Nabal which means 'Fool.' Compound names have more than one element, and while some are epithets (e.g. Obadiah = "Servant of Yahweh"), most form a sentence (e.g. Elijah = "My God is Yahweh"; Nathaniel = "God had given"). Almost all compound names have a religious significance, simple names frequently have not. Another further distinction that is noticeable between simple names and compound names is that early personal names among the Hebrews were usually simple, but after the exile, the compound names became visible among the Israelites. As it has been mentioned earlier on that some factors induced names to be given to a child among the Hebrews, these factors will be highlighted with examples of simple names. Majority of these examples would be largely drawn from those presented by Gray, Abba, and Roland.

(a) Names Denoting Circumstances of Birth - There are many examples of simple names among the Hebrews whose meanings denoted or reflected the circumstances that surrounded the birth of the child. Examples include names like "Yathom," "Yathomah," which occur in the Elephantine papyri, which means "orphan" or "fatherless" and they were probably given to posthumous children. Gray explains that Noldeke would interpret "Jotham" and "Akikub" in the same way. But both these names are ambiguous and may be differently explained. The mother of "Azubah" meaning "Forsaken," may have died at child-birth. "Ahab" means "father's brother," which explained the relationship established by the birth. In this line, "Ahumal" may mean "Brother of my mother." The idea is that the new-born child will at some future time stand by his mother, as if he were her brother. "Jacob" which means "Supplanter" was so called because while still in his mother's womb he grasped the heel "ageb" of his 
twin brother (Gen. 25:26). However, it must be pointed out that not all Hebrew names could be interpreted or explained literally with regard to the meanings of the Hebrew words which formed them.

The circumstance of birth may be an event contemporaneous with the birth. For example, the wife of Phinehas, hearing that the Philistines had captured the Ark of covenant, gave birth to a son prematurely and she named the son "Ichabod" meaning "Inglorious" or "the glory has departed" or "where is the glory?" (1 Sam. 4:21). There are also names that refer to the time of birth, i.e. a festive period. Examples include "Haggai," a very popular name after the $6^{\text {th }}$ century, meaning "festal" i.e. born at the feast, and "Haggith" has the same meaning. "Shabbethai" means "Sabbatical" i.e. born on the Sabbath.

(b) Names Indicating Physical Characters - There are names that describe the physical features of the child. This category can be further divided into the following:

(i) Names denoting sex - The name "Geber" means "man" or "male" (Job $3: 3)$.

(ii) Names denoting size of the child - The name "Hakkatan" means "the small one" rather than the youngest.

(iii) Names denoting colour - "Edom" (Esau) means "Red" (Gen. 25:25); "Laban," "Lebanah," "Libni," "Labani," (Babylonian name) may all mean "white;" "Harus" means "yellow;" "Zohar" means "reddish white;" "Sheharhor," a name probably occurring on a Hebrew seal, meaning "black."

(iv) Names denoting defects in the child at birth - Examples of such names include "Kareah" meaning "Baldness," "Heresh" meaning "dumbness," "Ikkesh" meaning "crookedness," "Gareb" means "Scabbiness," "Zeruah" means "leprosy," "Paseah" means "the lame," and "Harum" or "Harumaph" may mean "with slit nose."

(v) Names derived from animals - Names of animals were commonly used, especially in the early ages because the animal in question may conspicuously suggest physical characteristics or qualities detected in the infant or which it was desired that the child should possess when grown up. Examples include "Rachel" meaning "Sheep," "Deborah" meaning "Bee," "Aiah" meaning "Vulture", "Zimri" meaning "a mountain Sheep", "Jonah" meaning "Dove", "Zibiah" meaning "Gazelle," "Huldah" meaning "Weasel", "Achbor" meaning "Mouse", "Shaphan" meaning "Rock-badger", "Nahash" meaning "Serpent," "Caleb" meaning "Dog", "Shephuphan" meaning "Viper," "Eglah" meaning "Heifer."

(vi) Names derived from plants or trees - Names taken from plants are much rarer. But few examples are discernible e.g. "Elon," or "Elim" or "Elah" means "Oak-tree," "Zeitan" or "Zayith" means "Olive," "Qos" means "thorn," "Tamer" means "Palm-tree," Hadassah" means "Myrtle," "Rimmon" means "Pomegranate," "Susanna" (from apocryphal) means "Lily." 
For names derived from animals and plants, some authors have maintained that these were originally names of clans, and that they were pointers to the primitive totemism among early Hebrews. For instance, Gray cited the example of Smith who finds as many as 150 divinities other than Yahweh through the examination of the Hebrew names as preserved in the Hebrew text. Smith also argues that there are only a small proportion of theophorous names which once existed in the Hebrew writing, but which have been mutilated by the removal of the strange god's name or by the substitution for it of El or Jahveh. Among these strange gods, Smith includes Baal, Melech (king), and also $A b$ (father), $A h$ (brother), and $A m$ (people). ${ }^{21}$ However, Abba and Roland are of the opinion that the names in question may not necessarily be totemistic, for they could be accounted for among the ancient Arabs and among the Bedouin of today, where such names are descriptive or expressive of a wish. For instance, a girl called "Deborah" could mean that the desire or wish of the parents for her would be that she would be as busy as a "Bee," a boy called "Caleb," "Shephuphan," or "Aiah" may mean that he would be strong or terrible to his enemies, like a dog, a viper or a vulture. Again, a child may be called after the first animal seen at the time of its birth. This custom still obtains with modern Bedouin. $^{22}$

(vii) Names denoting mental and moral qualities - Some names probably imply mental and moral qualities of the child, and those not always of a desirable kind. Examples include "Nabal" meaning "fool," "Nahor" meaning "the snorer," "Naomi" meaning "Pleasantness."

One thing that is clear from the analysis of some of the Yoruba and Hebrew names given is that they all have meanings and they are induced by certain prevailing circumstances, both positive and negative, at the time of birth. One of the reasons of this type of naming system is to keep both the parents and the child in remembrance of the period of birth or the status of the parents or an important event going on at the time of birth. This kind of naming system has helped in determining or calculating the date or period of birth of some aged people that were born when documentation of birth record was not popular. However, this cultural naming system has been displaced by the Pentecostals in favour of biblical name. Below are examples of some biblical names being changed to by the Pentecostals and their meanings. 


\begin{tabular}{|l|l|l|}
\hline S/No & Biblical Name & Meaning $^{23}$ \\
\hline 1 & Abel & Vanity \\
\hline 2 & Amos & Loading or weighty \\
\hline 3 & Barabbas & Son of Shame \\
\hline 4 & Caleb & A Dog, or a Cow or a Basket \\
\hline 5 & Cornelius & Of a horn \\
\hline 6 & Deborah & A Bee \\
\hline 7 & Dorcas & A female roe-deer \\
\hline 8 & Esther & Secret or hidden \\
\hline 9 & Gideon & $\begin{array}{l}\text { He that bruises or breaks; a } \\
\text { destroyer }\end{array}$ \\
\hline 10 & Jacob & Supplanter \\
\hline 11 & Leah & Weary; tired \\
\hline 12 & Martha & Who becomes bitter; Provoking \\
\hline 13 & Mary & Bitterness; Rebellion ${ }^{24}$ \\
\hline 14 & Paul & Small; Little \\
\hline 15 & Racheal & Sheep \\
\hline 16 & Rebekah & Fat; fattened, a quarrel appeased \\
\hline
\end{tabular}

\section{Critical Evaluation of Change of Name Phenomenon among the Yoruba Pentecostals}

It is to be noted that name changing is not a new phenomenon in its entirety. Emens has even justified the reason why a person may decide to change his or her name. To her, the fact that both the first and last names were chosen for children by people who do not know the personalities or the preferences of those children, and in that case the names had been chosen blindly for them and when those children grow up they can formally change their names. ${ }^{25}$ As a matter of fact, three stages of the phenomenon of change of names are discernible in Yoruba Christian history - the one perpetuated and engineered by the Christian missionaries, the one orchestrated by educated Africans and church leaders, and the one being initiated by Pentecostal believers in recent times in South-western Nigeria.

Scholars, such as Ajayi, ${ }^{26}$ Ayandele,${ }^{27}$ Adewale, ${ }^{28}$ and Omoyajowo, ${ }^{29}$ have given detailed analysis of how change of names came into the Nigerian scene with the advent of the Christian missionaries. When the missionaries came, they met the people worshipping their God through various divinities. However, because of lack of understanding of the peoples' culture and religion, the missionaries demonised the religion of the people, preaching that the traditional religion was pure worship of wood and stone and that Christianity was the only religion that guaranteed salvation to man. This condemnation of traditional religion, according to Adewale, had practical impact on the people in many 
ways. One of them was that many adherents of the traditional religion abandoned their religion, gave up family names like Ògúnsèye, Sàngókúnlé, Oyábùnmi, Ifábùnmi, etc., for biblical names like Jacob, Joseph, Isaac, Deborah, Mary, etc. Adewale observed that the implication of this change of names was serious. This is because names are very significant among the Yoruba. Firstly, they help to identify the bearers of the names with the family to which they belong, and secondly, names connected with divinities help to preserve the family cults. The Jewish names taken under the banner of Christianity marked a total rejection of the traditional religion and a replacement of the latter by the former. ${ }^{30}$

The second stage of change of name in Yoruba Christian history was associated with the rise of 'Ethiopianism' in the church. At this point in time European missionaries demonstrated cultural and ethnic racism towards Africans' participation in church government and leadership. This event inspired what is termed in the literature as 'Cultural Nationalism' among the educated Africans who were also prominent members in the established churches. One of the most significant events of this period, apart from the fact that it eventually led to various schisms, which formed the beginning of the African indigenous churches, was that educated Africans disdained European culture so much that they started dropping European ways of life which they had been used to. They shed off their European names and took up African names instead. Africans saw themselves bearing meaningless names in a society that attached a great deal of importance to names. Examples of such people include David Brown Vincent who became Mojola Agbebi, J. H. Samuel who became Adegboyega Edun, George William Johnson who became Oshokale Tejumade, to mention just a few. ${ }^{31}$ The third stage of the change of name in Yoruba Christian history is the one being orchestrated by the Pentecostals which this paper is directed at.

Horsley has traced how name changes were indicative of religious change in biblical antiquity just as their new religious experience and affiliation is one of the reasons being put forward by the Pentecostals for changing their names. But beyond religious change Horsley puts forward other factors that usually warrant change of names in antiquity such as enlistment as Roman citizen or when a male is adopted into a Roman family, the name is automatically changed and sometimes the slave may take up the name of his master. ${ }^{32}$ This may reflect a shift in self-perception for cultural or other reasons. For instance, Egyptians or Jews who took a second Greek name may, in many instances, have wanted to be perceived as assimilated to a hellenised milieu. ${ }^{33}$

Looking critically at the biblical names in the above table, one obvious fact is that majority, if not all of them have negative or undesirable meanings. Yet many of the Pentecostals who are changing their cultural names that are pregnant with meaningful import are taking up some of these biblical names that may be considered even worse than the names they are changing from. It had been mentioned earlier that one of the reasons given by the Pentecostals for changing their traditional names is because of the evil connotation or negative meanings those names have (in their own perception, of course). As a matter of 
fact, it is part of the doctrinal emphases in the Mountain of Fire and Miracles Ministries (MFM) for all new converts that have traditional names that have negative meanings or that attached them to the family gods or tradition to undergo foundation check-up and deliverance where they would be severed from the family gods and be freed from the curse or the problems attached to the traditional name and the name must be changed and a new name taken up. ${ }^{34}$ Now that they are now still changing to biblical names that are having negative meanings or are indicative of undesirable vices, how then can one describe the action of the Pentecostals? Is it an issue of ignorance in their new found faith or a travesty?

It is to be noted that the Pentecostals believe that the meaning of a person's name has a lot of influence on who the person grows up to become in life. And that is in tandem with the Yoruba belief and aphorism that oruko omo a má ro omo (meaning that a child's name has influence on it). If this is so, how then will one explain the action of the Pentecostals who are changing their names prefixed with the names of divinities or those related to the ancestors/ancestresses or those that have negative meanings to names like Abel that means vanity? The meaning of this name also indicates the fact that the person bearing it is likely to be meeting with failure and disappointment in whatever he or she does because the outcome of his or her efforts will amount to vanity. Likewise Dorcas whose meaning is that of an animal, a female deer. To the average Yoruba, the name would have been interpreted that the bearer would be characterized by the spirit of beast. ${ }^{35}$ If the person should behave irrationally, the people would say "what do you expect from someone who is bearing animal name?"

From the interview conducted with some Pentecostals who are bearing some of the names highlighted in the table above to know whether they understand that their names have negative meanings and what are the factors that have motivated them to retain that name and not change them, the common denominator in their answers is that they do not give detail attention to the meaning of the biblical names rather they focused on the character and the significant role those biblical personages played in the biblical narratives. For example, Abel (Gen. 4:1-8) was the man who offered acceptable sacrifice, an action which is desirable for every Christian; Dorcas (Acts 9:36-43) was the hospitable and generous woman being loved by everyone around her, a virtue expected from all Christians; Gideon (Judg. 6:11-14), even though means destroyer, but he was the man who came from an humble background and was mightily used by God to deliver Israel from the Midianites' invasion and oppression; Mary (Lk. 10:38-42; Jn. 11:1-44) that means bitterness, is preferred because that is the name of the Mother of Jesus. And another Mary was the sister of Martha that was attentive to Jesus' word and was commended for her concern for spiritual things. She was also the lady that anointed Jesus' feet with the costly ointment in preparation of Jesus' body for his death and who was commended that her action would forever be remembered, just to mention a few. ${ }^{36}$ 
In view of the above, about three emerging patterns of naming tradition is noticeable among the Yoruba Pentecostals. The first is the fact that the family history, family occupation, family deity or birth circumstances are no longer taken into consideration in the choice of names they bear or give to their children. The second is the fact that in the choice of biblical names they bear or give to their children, the meaning of the names, the reason why they are changing their traditional or cultural names, are not given adequate consideration. Rather, the behavioural pattern, spiritual achievement and commendable acts of the biblical character in question are taken into consideration even though the name itself has negative and undesirable meaning. The third pattern, arising from the second is that naming among the Pentecostals is now "Prophetic" or "aspiration names" that are meant to predict or foretell or declare what they intend to become in life. That is the reason why names such as Praise, Glory, Excellent, Goodluck, Innocent, Peace, etc., are given to their children to the detriment of Yoruba names. Doyin Adeoye also corroborates the assertion when she says that "However, in recent times, many of these names (traditional names) are being replaced with the likes of Sharon, Miracle, Shiloh, Praise and Stephanie, Excel, Goodluck, Success, Hope, Wonderful, Rejoice, Favour, Goodness, McDonald, Marvellous and others, with the trend shifting from circumstances oriented." 37

One major observation from this phenomenon is that many of the Pentecostals, especially in urban centres, hardly include Yoruba names in the names given to their children during naming ceremonies. This attitude has serious negative implication for the sustenance of Yoruba culture and identity as I have argued elsewhere. ${ }^{38}$ One vital fact that the Pentecostals have refused to understand is that many of those biblical names they are taking up are themselves being influenced by the cultures of the Hebrews and Greco-Roman world where Christianity developed. Smith has argued for the traces of Semitic polytheism found in the Old Testament's proper names. This included the names of their divinities other than the God of Israel contrary to the opinion of other scholars. $\mathrm{He}$ is of the opinion that monotheism did not prevail in Israel before the fall of Jerusalem in 586 B.C.E. ${ }^{39}$ The thrust of his argument is that names among the Jews during the pre-exilic times cannot be divested from names of other divinities they were worshipping apart from the God of Israel. The fact that the Pentecostals now come in contact with these cultures through conversion to Christianity does not mean that they have to discard their own culture and identity or look down on their cultural values as inferior to the new culture they are changing to. As a matter of fact, Ojo has described this incidence as the erosion of Nigerian cultural values in favour of neocolonialism and western imperialism. $^{40}$ 


\section{Conclusion}

The argument of this paper has been the fact that though Yoruba Pentecostals detest traditional or cultural names that have negative meanings, owing to the belief of some that the life vicissitudes they are experiencing are as a result of the names they bear. As a result, they are taking up biblical names. However, it is observed that some of the biblical names they are changing to also have negative meanings. Then the question has been asked that is this action of the Pentecostals reasonable? One expects that if a person is quitting an activity because of its danger and negative implication, he or she is not expected to engage in an activity that will be at par with the former one in terms of negativity attached. This action of the Pentecostals has, therefore, been seen as travesty of name changing which does not worth its sort. It portrays the Yoruba Pentecostals as not having deep thinking on the implication of their action. If their argument has been the fact that they appreciate the godly acts of the biblical personages after whom they chose their names and not the meaning of their names, are there not people who have bore the traditional names they changed from and who had done commendable things? Why can't they pattern their lives after those people? In essence, even though it may seem unwittingly to them, the Yoruba Pentecostals are among the forces that are contributing to the disappearance of Yoruba cultural names that is germane to the survival of Yoruba culture and identity. 


\section{Notes and References}

1. In the interviews conducted in 2007, four out of every five Christians who changed their names are Pentecostals. As a matter of fact, those Christians who changed their names from the mainline churches have been so influenced by the teachings of the Pentecostal preachers on the subject.

2. S. O. Olanisebe, "Change of Names in Gen. 17.1-22 and Among Yoruba Pentecostals: A Comparative Investigation," Asia Journal of Theology Vol. 25, No. 2 (2011), 288-314.

3. J. O. Lucas, The Religion of the Yorubas (Lagos: CMS, 1948), 8-9.

4. N. A. Fadipe, The Sociology of the Yoruba (Ibadan: Ibadan University Press, 1970), 29.

5. J. A. Atanda, Introduction to Yoruba History (Ibadan: Ibadan University Press, 1980), 1.

6. J. A. Sofola, African Culture and the African Personality (Ibadan: African Resources Publishers, 1978), 66-123.

7. M. Oduyoye, Yoruba Names: Their Structures and their Meanings (Ibadan: Sefer, 2001), 61-63.

8. E. F. Emens, "Changing Name Changing: Framing Rules and the Future of Marital Names," The University of Chicago Law Review Vol. 74, No. 3 (2007), 769.

9. J. O. Awolalu and P. A. Dopamu, West African Traditional Religion (Ibadan: Onibonoje Press, 1979), 36.

10. S. B. Cohen and Nurit Kliot, "Place-Name in Israel's Ideological Struggle over the Administered Territories," Annals of the Association of American Geographer Vol. 82, No.4 (1992), 655.

11. Akintunde Akinyemi, "Integrating Culture and Second Language Teaching through Yoruba Personal Names," The Modern Language Journal Vol. 89, No. 1 (2005), 115-116.

12. J. A. Sofola, African Culture and the African Personality, 117-118.

13. J. S. Mbiti, Introduction to African Religion (London: Heinemann, 1975), 88.

14. J. A. Sofola, African Culture and African Personality, 110-111.

15. J. S. Mbiti, Introduction to African Religion, 89.

16. T. N. O. Quarcoopome, West African Traditional Religion (Ibadan: African Universities Press, 1987), 111.

17. Interview conducted with a respondent at Ile-Ife, $15^{\text {th }}$ May, 2007.

18. P.O. Abioje, African Ancestral heritage in Christian Interpretations (Cape Coast: Department of Religion and Human Values, University of Cape Coast, 2014), 18.

19. M. Oduyoye, Yoruba Names, 73-75.

20. R. Abba, "Name," in The Interpreter's Dictionary of the Bible Vol. 3. (Nashville: Abingdon Press, 1989), 503. 
21. G. B. Gray, "Names (Hebrew)," in Hastings, J. (ed.) Encyclopaedia of Religion and Ethics, Vol.9 (Edinburgh: T. \& T. Clark, 1958), 161.

22. Gray, 155-159; Also in R. Abba, "Name," in The Interpreter's Dictionary of the Bible, 504- 505; Also in O. P. Roland, Ancient Israel: Its Life and Institutions. Translated by McHugh, John. (London: Darton, Longman and Todd, 1962), 43-44.

23. All the meanings of these biblical names, except otherwise indicated, have been gotten from R. D. Hitchcock, An Interpreting Dictionary of Scripture Proper Names, New York, 1869, accessed at www.biblestudytools.com/dictionaries/hitchcocks-bible-names on 6th March 2014.

24. Marriage Counselling, Names and Meaning (Lagos: Emeka Philips, 2005), 30.

25. E. F. Emens, "Changing Name Changing: Framing Rules and the Future of Marital Names," 768.

26. J. F. A., Ajayi, Christian Missions in Nigeria 1841-1891: The Making of a New Elite (Essex: Longman, 1981).

27. E. A. Ayandele, The Missionary Impact on Modern Nigeria 1842-1914: A Political and Social Analysis (London: Longman, 1971).

28. S. A. Adewale, The Interaction of Religions in Nigeria (Isolo, Lagos: Sudan Commercial Press, 1994).

29. A. Omoyajowo, Religion, Society and the Home (Ijebu-Ode: Vicoo International Press, 2001), 63-74.

30. S. A. Adewale, The Interaction of Religions in Nigeria, 71.

31. E. A. Ayandele, The Missionary Impact on Modern Nigeria 1842-1914, 257-258.

32. G. H. R. Horsley, "Name Change as an Indication of Religious Conversion in Antiquity," Numen Vol. 34, Fasc.1 (1987), 1.

33. G. H. R. Horsley, "Name Change as an Indication of Religious Conversion in Antiquity," 2.

34. S. O. Olanisebe, "Name-Changing as the Game-Changer: A Re-Reading of Gen. 32;22-28 in the Light of the Custom of Changing Names among Yoruba Pentecostals in Nigeria," Asia Journal of Theology Vol. 27, No. 2 (2013), 260-274.

35. Christian Matthew, More Information about Changing Questionable Names (Ibadan: Chrismat Publication, 2004), 11.

36. Information gotten from the interview conducted with some Pentecostals at Ile-Ife between January and March 2014.

37. Doyin Adeoye, "Names: What's the New Influence?" At http://www.tribune.com.ng/component/k2/item/2533-names-what-s-thenew-influence, accessed on 02/4/2014.

38. S. O. Olanisebe, "Religio-Cultural Implications of Name-Changing in the Old Testament and among Yoruba Pentecostals for the Re-Branding 
Nigeria Campaign," African Journal of Biblical Studies Vol. xxviii, No. 1 (2010), 61-65.

39. H. P. Smith, "Theophorous Proper Names in the Old Testament," American Journal of Semitic Languages and Literatures Vol. 24, No. 1 (1907), 34-35.

40. Jide Ojo, "The Erosion of Nigerian Cultural Values," at http://www.punchng.com/opinion/the-erosion-of-nigerian-culturalvalues/accessed on 02/04/2014 


\section{BLANK}

